\title{
LIMA ALAT UKUR ANALISIS BISNIS MANAJEMEN STRATEGI DALAM MERENCANAKAN DAN MENGEVALUASI TARGET BISNIS
}

\author{
Djaka Suryadi \\ STAI Asy-Syukriyyah Tangerang \\ djaka.suryadi01@gmail.com
}

\begin{abstract}
Strategy management is a continuous process that functions to evaluate and control the businesses and industries in which the organization is involved. One of the main roles of strategic management is to fully combine the various functional areas of the organization, as well as, to ensure these functional areas are well aligned and integrated. Another role of strategic management is to continue to oversee the goals and objectives of the organization. The results of the analysis of strategic management there are 5 business analysis strategies that can be used as benchmarks, for top management in evaluating and copying business strategies that have been planned and determined by the company, including: BCG analysis, PESTLE analysis, Porter analysis, GE-MC Kinsey analysis, SWOT analysis.
\end{abstract}

Keyword: Strategy Management, business analysis: BCG, PESTLE, SWOT, GE - Mc Kinsey, and Porter

\section{PENDAHULUAN}

Manajemen strategis tidak lain adalah perencanaan untuk kemungkinan yang dapat diprediksi maupun yang tidak mungkin. Ini berlaku untuk organisasi kecil maupun besar bahkan organisasi terkecil sekalipun menghadapi persaingan dan, dengan merumuskan dan menerapkan strategi yang tepat, mereka dapat mencapai keunggulan kompetitif yang berkelanjutan.

Ini adalah cara para ahli strategi menetapkan tujuan dan melanjutkan untuk mencapainya. Ini berkaitan dengan membuat dan menerapkan keputusan tentang arah organisasi di masa depan. Ini membantu kita mengidentifikasi arah pergerakan organisasi.

Manajemen strategis adalah proses berkelanjutan yang mengevaluasi dan mengendalikan bisnis dan industri di mana organisasi terlibat; mengevaluasi pesaing dan menetapkan tujuan dan strategi untuk memenuhi semua pesaing yang ada dan potensial; dan kemudian mengevaluasi kembali strategi secara berkala untuk menentukan bagaimana itu telah diterapkan dan apakah itu berhasil atau perlu diganti.

Manajemen Strategis memberikan perspektif yang lebih luas kepada karyawan sebuah organisasi dan mereka dapat lebih memahami bagaimana pekerjaan mereka cocok dengan 
keseluruhan rencana organisasi dan bagaimana hal itu terkait bersama dengan anggota organisasi lainnya. Ini tidak lain adalah seni mengelola karyawan dengan cara yang memaksimalkan kemampuan mencapai tujuan bisnis. Karyawan menjadi lebih dapat dipercaya, lebih berkomitmen dan lebih puas karena mereka dapat saling berhubungan dengan sangat baik dengan masing-masing tugas organisasi. Mereka dapat memahami reaksi dari perubahan lingkungan pada organisasi dan kemungkinan respon organisasi dengan bantuan manajemen strategis. Dengan demikian karyawan dapat menilai dampak dari perubahan tersebut pada pekerjaan mereka sendiri dan secara efektif dapat menghadapi perubahan tersebut. Manajer dan karyawan harus melakukan hal-hal yang sesuai dengan cara yang tepat. Mereka harus efektif sekaligus efisien.

Salah satu peran utama manajemen strategis adalah untuk menggabungkan berbagai area fungsional organisasi sepenuhnya, serta, untuk memastikan area fungsional ini selaras dan disatukan dengan baik. Peran lain dari manajemen strategis adalah untuk terus mengawasi tujuan dan sasaran organisasi.

Berdasarkan uraian di atas ada beberapa strategi analisis bisnis dalam manajemen strategi yang sering dijadikan acuan oleh manajemen puncak dalam rangka menjadikannya sebagai tools dalam menyerdahanakan strategic busisness plan dalam kerangka berpikir strategis dan aplikatif yang dapat dijadikan guidline bagi seluruh lini bisnis untuk dapat menjelaskan kepada para pihak terkait demi menunjang pencapaian strategi bisnis yang ditetapkan, didasarkan pada analisis lapangan baik bersifat makro maupun mikro yang terjadi dari suatu perencanaan yang sesuai dengan berbagai bidang bisnis yang dimilikinya.

\section{METODE PENELITIAN}

Tulisan ini merupakan hasil penelitian kepustakaan (library research). Jenis penelitian kepustakaan merupakan penelitian yang mengandalkan data-data yang hampir sepenuhnya dari kepustakaan atau literatur, baik itu dalam bentuk fisik maupun digital. Penelitian ini lebih popular dikenal dengan penelitian kualitatif deskriptif kepustakaan atau penelitian bibliografis, dan juga dapat diistilahkan Non Reaktif yang sepenuhnya menggunakan data-data yang bersifat teoritis dan dokumentasi yang ada di perpustakaan. 


\section{PEMBAHASAN}

\section{Strategi bisnis menggunakan Analisis Matrik Boston Consulting Group (BCG)}

BCG ditemukan oleh Bruce D. Henderson pada awal tahun 1970, sebagai divisi managemen dan konsultasi dari Boston Safe Deposit and Trust Company yang mana merupakan anak cabang dari perusahaan Boston. Seorang mantan penjual alkitab, Henderson sudah menjadi sarjana teknik di Universitas Vanderbilt sebelum berkunjung sekolah bisnis Harvard. Beliau meninggalkan HBS 90 hari sebelum kelulusannya untuk bekerja di perusahaan Westinghouse, tempat dimana ia menjadi wakil presiden termuda sepanjang sejarah perusahaan tersebut. Dia akan meninggalkan Westinghouse untuk memimpin Unit manajemen pelayanan sebelum menerima tantangan yang mustahil dari pimpinan Boston Safe Deposit and Trust Company untuk memulai pelayanan konsultasi untuk bank. ${ }^{1}$

Boston Consulting Group (BCG) adalah perusahaan konsultan manajemen swasta yang berbasis di Boston. Boston Consulting Grup merupakan perusahaan yang berkecimpung dalam hal perkembangan pangsa pasar. BCG dikembangkan dan dipopulerkan pertama oleh seorang manajemen konsultan terkemuka. ${ }^{2}$

"The BCG matrix is a chart that had been created by Bruce Henderson for the Boston Consulting Group in 1970 to help corporations with analyzing their business units or product lines. This helps the company allocate resources and is used as an analytical tool in brand marketing, product management, strategic management, and portfolio analysis".

Artinya Matriks Boston Consulting Grup adalah bagan yang diciptakan oleh Bruce Henderson untuk Boston Consulting Group pada tahun 1970 untuk membantu perusahaan dengan menganalisis unit bisnis atau lini produk mereka. Matriks BCG membantu perusahaan mengalokasikan sumber daya dan digunakan sebagai alat analitis dalam merek pemasaran, manajemen produk, manajemen strategis, dan analisis portofolio. ${ }^{3}$

Matrik Boston Consulting Group (BCG) adalah membagi sebuah daerah dengan dua garis yaitu vertikal dan horizontal menjadi empat daerah (kuadran). Empat daerah tersebut diberi nama yaitu tanda tanya (question mark), bintang (star), sapi perah (cash cow) dan Anjing (dog).

${ }^{1}$ Yanuar Surya Putra, Analisis Matriks Boston Consulting Grup (BCG) pada Sepeda Motor Merek Honda (Studi Kasus pada PT. Astra Honda Motor Tahun 2013,) Vol. 7 No. 13, Juli 2014, h. 53. Stieama.ac.id diakses pada tanggal 2 July 2020, pukul 14:13.

${ }^{2}$ M. Yusuf S. Barusman dan Soni Gunardi, Analisis Portofolio Produk pada PT. Asuransi Umum Bumi Putera Muda 1967 Cabang Lampung menggunakan Matrik Baston Consulting Group, Vol. 4 No. 2 April 2014 h.141. ubl.ac.id diakses pada tanggal 02 July 2020, pukul 14:06.

${ }^{3}$ Yanur Suya Putra, Analisis Matrik Baston Consulting Group (BCG) pada Sepeda Motor Merek Honda..., h. 53. stieama.ac.id diaksas pada tanggal 02 July 2020, pukul 14:13. 


\section{Box dan Portfolio Diagram (Diagram Portofolio).}

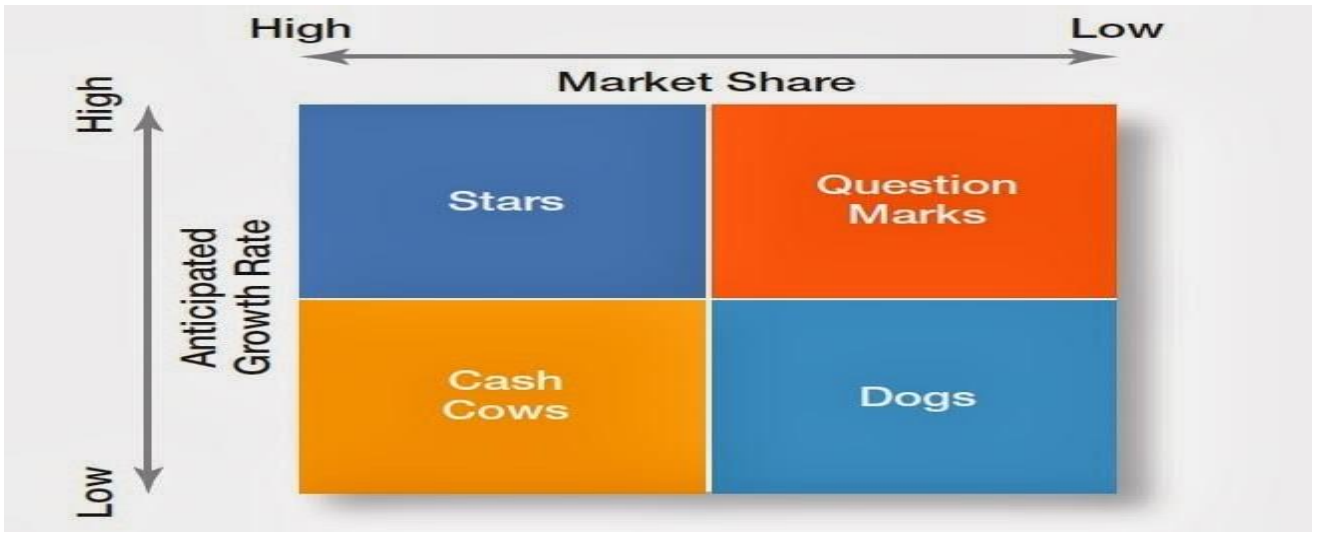

\section{Question Marks (Tanda Tanya)}

Produk atau bisnis unit yang memiliki prospek pertumbuhan yang tinggi tetapi pangsa pasarnya masih sangat rendah. Penghasilan (uang) yang didapat umumnya tidak sebanding dengan biaya-biaya yang dikeluarkan (lebih banyak pengeluaran daripada pendapatan). Namun karena prospek pertumbuhannya sangat pesat sehingga berpotensi untuk berubah menjadi Stars atau Bintang. Manajemen perusahaan tersebut disarankan untuk tetap berinvestasi pada produk atau bisnis unit yang berada dalam kategori Question Marks ini karena pertumbuhan yang tinggi.

\section{Stars (Bintang)}

Produk atau unit bisnis yang memiliki pangsa pasar yang dominan dan pertumbuhan yang cepat serta menghasilkan uang (pendapatan) yang besar. Ini berarti produk-produk yang dihasilkan merupakan produk-produk terkemuka yang diminati oleh pasar. Perusahaan membutuhkan banyak investasi untuk mempertahankan posisi produk-produk tersebut dan untuk mendukung pertumbuhan lebih lanjut serta mempertahankan keunggulan-keunggulan atas produk tersebut agar dapat tetap bersaing dengan produk kompetitor lainnya. Produk-produk di kategori Bintang ini dapat berubah menjadi kategori Sapi perah (Cash Cows) apabila mereka tetap dapat mempertahankan keberhasilan mereka hingga tingkat pertumbuhannya mengalami penurunan.

\section{Cash Cows (Sapi Perah)}

Produk atau unit bisnis yang merupakan pemimpin pasar, menghasilkan uang atau pendapatan yang lebih banyak dibandingkan dengan biaya yang dikeluarkan oleh perusahaannya. Produk atau unit bisnis pada kategori ini memiliki pangsa pasar yang tinggi namun prospek pertumbuhan kedepan akan sangat terbatas. Pendapatan yang didapat pada tingkat Cash Cows ini 
biasanya digunakan sebagai pendanaan untuk penelitian dan pengembangan produk-produk baru yang masih berada di kategori Question Marks (Tanda Tanya). Kondisi ini juga digunakan untuk membayar hutang-hutang perusahaan serta membayar dividen kepada pemegang saham. Perusahaan disarankan untuk tetap berinvestasi pada produk-produk dalam kategori Cash Cows ini untuk mempertahankan produktivitas dan kualitas atau dapat juga dijadikan pendapatan pasif bagi perusahaan.

\section{Dogs (Anjing)}

Produk atau unit bisnis yang memiliki pangsa pasar rendah dan mengalami tingkat pertumbuhan yang rendah. Produk-produk pada kategori ini biasanya hanya memberikan kontribusi keuntungan yang sangat rendah atau bahkan harus menderita kerugian. Produk atau bisnis unit kategori Dogs ini umumnya merupakan beban bagi perusahaan karena dapat menguras waktu manajemen dan sebagian besar sumber daya perusahaan. Unit bisnis atau produk yang telah berada pada kategori ini biasanya akan mengalami pengurangan, divestasi ataupun likuidasi oleh manajemen perusahaan.

\section{Strategi bisnis menggunakan Analisis PESTLE}

PESTLE Analysis adalah metode analisis yang digunakan untuk mengidentifikasi faktor faktor eksternal yang mempengaruhi suatu organisasi. PESTLE Analysis dapat digunakan untuk mempertimbangkan faktor-faktor permasalahan eksternal, yaitu Political, Economic, Social, Technology, Legal, dan Environment.

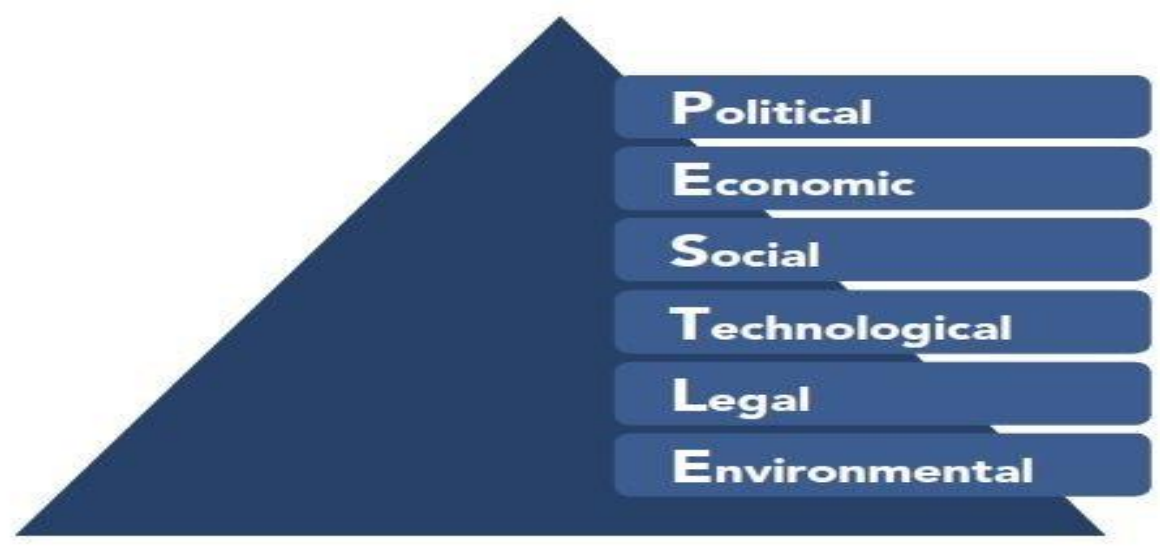

Political, Faktor politik meliputi hukum yang berlaku, kebijakan pemerintah, dan aturan formal atau informal di lingkungan perusahaan (Contoh : kebijakan pajak dan peraturan daerah). 
Economic, Faktor ekonomi meliputi semua faktor yang mempengaruhi daya beli dari customer dan mempengaruhi iklim berbisnis suatu perusahaan (Contoh : standar nilai tukar, suku bunga, dan pertumbuhan ekonomi).

Social, Faktor sosial meliputi semua faktor yang dapat mempengaruhi kebutuhan dari pelanggan dan mempengaruhi ukuran dari besarnya pangsa pasar yang ada (Contoh : tingkat pendidikan masyarakat, tingkat pertumbuhan penduduk, kondisi lingkungan sosial dan lingkungan kerja).

Technological, Faktor teknologi meliputi semua hal yang dapat membantu dalam menghadapi tantangan bisnis dan mendukung efisiensi proses bisnis perusahaan (Contoh : penemuan dan pengembangan baru, biaya dan penggunaan teknologi, perubahan dalam ilmu pengetahuan, dan dampak dari perubahan teknologi).

Legal, Faktor legal meliputi pengaruh hukum seperti perubahan undang-undang yang ada atau yang akan datang (Contoh : kesehatan dan keselamatan, arahan pekerjaan, hak asasi manusia, tata kelola perusahaan, dan tanggung jawab lingkungan).

Environment, Faktor lingkungan dapat digunakan ketika melakukan perencanaan strategis atau mencoba mempengaruhi keputusan pembeli seperti faktor lokasi geografis.

\section{Analisis PESTLE}

PESTLE Analysis menyediakan kerangka yang dapat digunakan untuk menginvestigasi lingkungan eksternal dengan menggunakan pertanyaan pada setiap faktor - faktor tersebut dan mendiskusikan yang mungkin memiliki keterlibatan. Berikut adalah tipe - tipe pertanyaan yang mungkin digunakan:

1. Apa saja faktor - faktor dari kunci politik?

2. Apa saja faktor- faktor ekonomi yang penting?

3. Apa saja aspek kebudayaan yang penting?

4. Apa inovasi teknologi yang mungkin tercipta?

5. Apakah mungkin undang - undang yang saat ini dan yang akan datang mempengaruhi industri?

6. Apa saja pertimbangan lingkungan yang dilakukan?

PESTLE tools adalah teknik yang sangat kuat untuk menganalisis lingkungan perusahaan, tetapi harus dapat terwakili hanya dengan satu komponen dari sebuah proses analisis strategi yang komprehensif (keseluruhan). 
Use a PESTLE Analysis when:

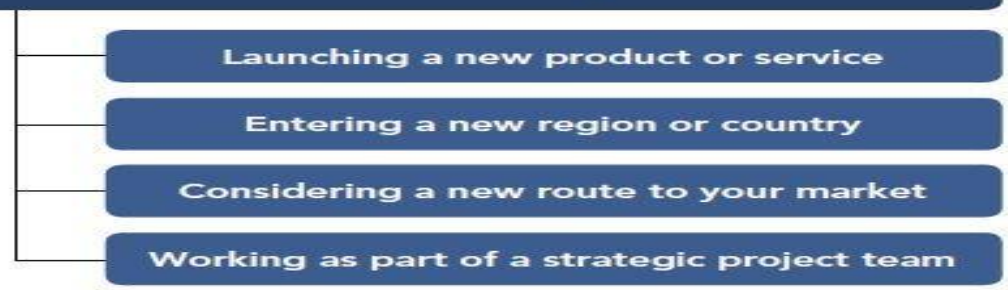

Berikut adalah gambaran proses yang dilakukan ketika menggunakan teknik PESTLE, yaitu:

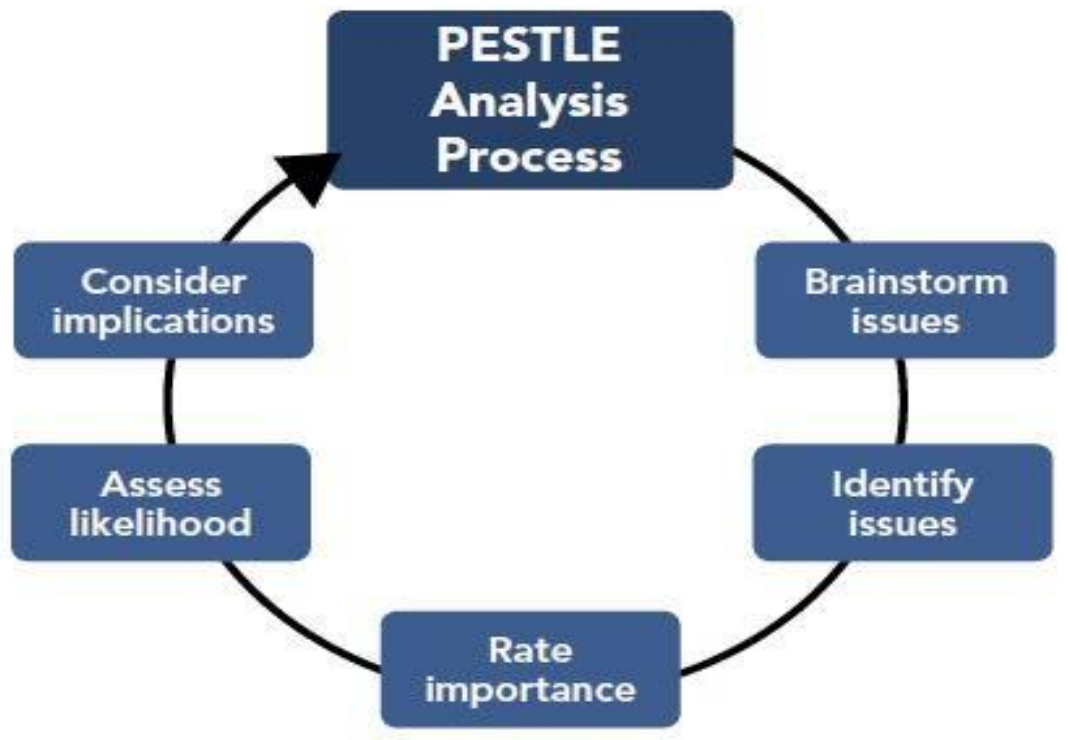

Bertukar pemikiran dan mendaftar masalah utama yang diluar pengawasan organisasi untuk menghasilkan ide penyelesaian masalah.

1. Mengidentifikasi secara luas pengertian dari setiap masalah yang ada.

2. Mengurutkan hal - hal yang relatif penting untuk organisasi.

3. Memperkirakan kemungkinan permasalahan yang akan terjadi.

4. Mempertimbangkan secara singkat kesimpulan yang didapat jika masalah itu terjadi.

Untuk memaksimalkan penggunaan PESTLE Analysis, proses harus dilakukan secara teratur dalam sebuah organisasi untuk mengidentifikasi setiap tren. Teknik PESTLE dapat membantu mengklarifikasi mengapa perlu adanya perubahan dan mengidentifikasi pilihan - pilihan yang berpotensi. Tentunya dari setiap teknik analisis terdapat keuntungan dan kerugian dalam menggunakan teknik PESTLE, yaitu sebagai berikut :

\section{Keuntungan PESTLE Analysis:}

1. Menyediakan kerangka yang sederhana dan mudah digunakan untuk proses analisis. 
2. Melibatkan keahlian dan kerja sama tim dalam proses analisis.

3. Membantu untuk mengurangi dampak dan efek dari potensi ancaman pada organisasi.

4. Membantu dan mendorong pengembangan dari pemikiran strategis dalam organisasi.

5. Menyediakan sebuah cara kerja yang memungkinkan organisasi untuk mengidentifikasi dan mengeksploitasi peluang baru.

6. Memungkinkan untuk mengevaluasi impilkasi dari proses memasuki pasar baru dalam skala nasional dan internasional.

\section{Kerugian PESTLE Analysis:}

Pengguna dapat menganggap mudah informasi yang digunakan untuk menentukan keputusan.

1. Proses tersebut harus diadakan secara teratur untuk menjadi efektif dan seringkali organisasi tidak melakukannya.

2. Pengguna tidak harus menyerah untuk 'lumpuh dengan analisis' di mana mereka mengumpulkan terlalu banyak informasi dan lupa bahwa tujuan dari tools ini adalah mengidentifikasi masalah sehingga tindakan penyelesaian dapat diambil.

3. Organisasi sering membatasi siapa yang terlibat karena waktu dan pertimbangan biaya. Ini membatasi efektivitas teknik sebagai kunci perspektif mungkin hilang dari diskusi.

4. Akses pengguna ke informasi kualitas eksternal sering dibatasi karena biaya dan waktu yang diperlukan untuk menyusun itu.

5. Asumsi sering membentuk dasar untuk sebagian besar data yang digunakan, membuat keputusan apapun yang dibuat berdasarkan data subjektif.

\section{Strategi bisnis Analisis Lima Kekuatan Porter (Porter's Five Forces Analysis)}

Analisis Lima Kekuatan Porter atau dalam bahasa Inggris disebut denggan Portes's Five Forces Analysis adalah suatu alat yang sederhana namun sangat berguna untuk memahami dimana letak kekuatan perusahaan kita dalam menghadapi situasi persaingan di dunia bisnis. Dengan mengunakan Analisis Lima Kekuatan ini, kita dapat memahami kekuatan posisi persaingan saat ini dan kekuatan posisi persaingan pada bisnis yang sedang direncanakan.

Konsep Analisis Lima Kekuatan (Five Forces) ini pertama kali dikemukakan oleh Michael Porter dari Universitas Harvard pada tahun 1979. Michael Porter juga dikenal sebagai Bapak Strategi Bisnis Modern. Analisis Lima Kekuatan Porter atau Porter's Five Forces Analysis ini 
merupakan salah satu Analisis yang sering digunakan dalam Manajemen Strategi sebuah perusahaan. Analisis Lima Kekuatan Porter (Porter's Five Forces Analysis)

Seperti namanya, Porter's Five Forces Analysis ini mengunakan 5 Kekuatan Industri untuk menentukan intensitas persaingan dalam suatu industri. Berikut ini adalah kelima Kekuatan menurut Michael Porter atau lebih dikenal dengan Porter's Five Forces Analysis.

1. Threat of new entrants (Hambatan bagi Pendatang Baru),

Kekuatan ini menentukan seberapa mudah (atau sulit) untuk masuk ke industri tertentu. Jika Industri tersebut bisa mendapatkan profit yang tinggi dengan sedikit hambatan maka pesaing akan segera bermunculan. Semakin banyak perusahaan saingan (kompetitor) yang bersaing pada market yang sama maka profit atau laba akan semakin menurun. Sebaliknya, semakin tinggi hambatan masuk bagi pendatang baru maka posisi perusahaan kita yang bergerak di industri tersebut akan semakin diuntungkan, beberapa hambatan bagi para pendatang baru diantaranya adalah :
a. Memerlukan dana atau modal yang tinggi
b. Teknologi yang tinggi
c. Hak paten atau merek dagang
d. Skala ekonomi
e. Loyalitas pelanggan
f. Peraturan pemerintah

\section{Bargaining power of suppliers (Daya Tawar Pemasok)}

Daya tawar pemasok yang kuat memungkinkan pemasok untuk menjual bahan baku pada harga yang tinggi ataupun menjual bahan baku yang berkualitas rendah kepada pembelinya. Dengan demikian, keuntungan perusahaan akan menjadi rendah karena memerlukan biaya yang tinggi untuk membeli bahan baku yang berkualitas tinggi. Sebaliknya, semakin rendah daya tawar pemasok, semakin tinggi pula keuntungan perusahaan kita. Daya tawar pemasok menjadi tinggi apabila hanya sedikit pemasok yang menyediakan bahan baku yang diinginkan sedangkan banyak pembeli yang ingin membelinya, hanya terdapat sedikit bahan baku pengganti ataupun pemasok memonopoli bahan baku yang ada.

\section{Bargaining power of buyers (Daya Tawar Pembeli)}

Kekuatan ini menilai daya tawar atau kekuatan penawaran dari pembeli/konsumen, semakin tinggi daya tawar pembeli dalam menuntut harga yang lebih rendah ataupun kualitas produk yang lebih tinggi, semakin rendah profit atau laba yang akan didapatkan oleh perusahaan produsen. Harga 
produk yang lebih rendah berarti pendapatan bagi perusahaan juga semakin rendah. Di satu sisi, Perusahaan memerlukan biaya yang tinggi dalam menghasilkan produk yang berkualitas tinggi. Sebaliknya, semakin rendah daya tawar pembeli maka semakin menguntungkan bagi perusahaan kita. Daya tawar pembeli tinggi apabila jumlah produk pengganti yang banyak, banyak stok yang tersedia namun hanya sedikit pembelinya.

4. Threat of substitutes (Hambatan bagi Produk Pengganti)

Hambatan atau ancaman ini terjadi apabila pembeli/konsumen mendapatkan produk pengganti yang lebih murah atau produk pengganti yang memiliki kualitas lebih baik dengan biaya pengalihan yang rendah. Semakin sedikit produk pengganti yang tersedia di pasaran akan semakin menguntungkan perusahaan kita.

5. Rivalry among existing competitors (Tingkat Persaingan dengan Kompetitor)

Kekuatan ini adalah penentu utama, perusahaan harus bersaing secara agresif untuk mendapatkan pangsa pasar yang besar. Perusahaan kita akan semakin diuntungkan apabila posisi perusahaan kita kuat dan tingkat persaingan pada pasar (Market) yang sama tersebut yang rendah. Persaingan semakin ketat akan terjadi apabila banyak pesaing yang merebut pangsa pasar yang sama, loyalitas pelanggan yang rendah, produk dapat dengan cepat digantikan dan banyak kompetitor yang memiliki kemampuan yang sama dalam menghadapi persaingan.

\section{Strategi Bisnis menggunakan Analisis SWOT}

SWOT adalah singkatan dari Strength, Weakness, Opportunities, dan Threats. Seperti namanya, Analisis SWOT merupakan suatu teknik perencanaan strategi yang bermanfaat untuk mengevaluasi Kekuatan (Strength) dan Kelemahan (Weakness), Peluang (Opportunities) dan Ancaman (Threats) dalam suatu proyek, baik proyek yang sedang berlangsung maupun dalam perencanann proyek baru. Analisis SWOT bukan hanya dapat digunakan dalam bisnis, tetapi juga dapat digunakan pada pribadi kita sendiri dalam pengembangan karir.

Analisis SWOT pertama kali diperkenalkan oleh Albert S Humphrey pada tahun 1960-an dalam memimpin proyek riset di Stanford Research Institute yang menggunakan data dari perusahaan-perusahaan Fortune 500. 


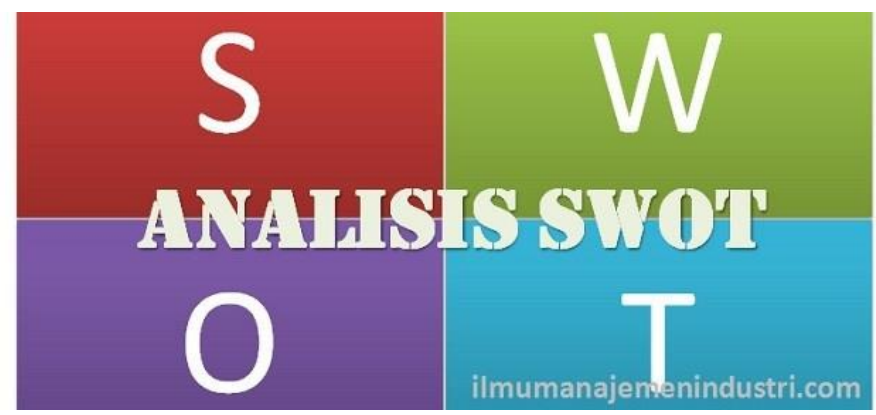

\section{Komponen - komponen Dasar Analisis SWOT}

Analisis SWOT terdiri dari 4 komponen dasar yaitu :

a. Strength (Kekuatan) atau disingkat dengan "S", yaitu karakteristik organisasi ataupun proyek yang memberikan kelebihan / keuntungan dibandingkan dengan yang lainnya.

b. Weakness (Kelemahan) atau disingkat dengan "W", yaitu karakteristik yang berkaitan dengan kelemahan pada organisasi ataupun proyek dibandingkan dengan yang lainnya.

c. Opportunities (Peluang) atau disingkat dengan "O”, yaitu Peluang yang dapat dimanfaatkan bagi organisasi ataupun proyek untuk dapat berkembang di kemudian hari.

d. Threats (Ancaman) atau disingkat dengan "T", yaitu Ancaman yang akan dihadapi oleh organisasi ataupun proyek yang dapat menghambat perkembangannya.

Dari keempat komponen dasar tersebut, Strength (kekuatan) dan Weakness (Kelemahan) adalah faktor internal organisasi/proyek itu sendiri, sedangkan Oppoturnities (Peluang) dan Threats (Ancaman) merupakan faktor eksternal yang mempengaruhi perkembangan organisasi ataupun proyek. Oleh karena itu, Analisis SWOT juga sering disebut dengan Analisis Internal-Eksternal (Internal-External Analisis) dan Matriks SWOT juga sering dikenal dengan Matrix IE (IE Matrix).

\section{Strategi bisnis menggunakan analisis model General electric Mc Kinsey}

Matriks sembilan kotak GE-McKinsey adalah alat strategi yang menawarkan pendekatan sistematis bagi perusahaan multi-bisnis untuk memprioritaskan investasinya di antara unit-unit bisnisnya. GE-McKinsey adalah kerangka kerja yang mengevaluasi portofolio bisnis, memberikan implikasi strategis lebih lanjut dan membantu memprioritaskan investasi yang dibutuhkan untuk setiap unit bisnis (BU)

Di dunia bisnis, seperti di tempat lain, masalah kelangkaan sumber daya memengaruhi keputusan yang dibuat oleh perusahaan. Dengan sumber daya yang terbatas, tetapi banyak peluang untuk menggunakannya, bisnis harus memilih cara menggunakan uang tunai mereka yang terbaik. 
Perjuangan untuk investasi terjadi di setiap tingkat perusahaan: antara tim, departemen fungsional, divisi atau unit bisnis. Pertanyaan tentang di mana dan berapa banyak yang harus diinvestasikan adalah suatu hal yang membingungkan bagi mereka yang mengalokasikan sumber daya.

Bagaimana ini mempengaruhi bisnis yang terdiversifikasi? Perusahaan multi bisnis mengelola portofolio bisnis yang kompleks, seringkali, dengan sebanyak 50, 60 atau 100 produk dan layanan. Produk atau unit bisnis berbeda dalam hal apa yang mereka lakukan, seberapa baik kinerjanya atau prospek masa depannya. Ini membuat sangat sulit untuk membuat keputusan di mana produk yang harus diinvestasikan oleh perusahaan. Setidaknya, itu sulit sampai matriks BCG dan versi perbaikannya matriks GE-McKinsey datang untuk membantu. Alat-alat ini memecahkan masalah dengan membandingkan unit-unit bisnis dan memasukkan mereka ke kelompok-kelompok yang layak diinvestasikan atau kelompok-kelompok yang harus dipanen atau didivestasi.

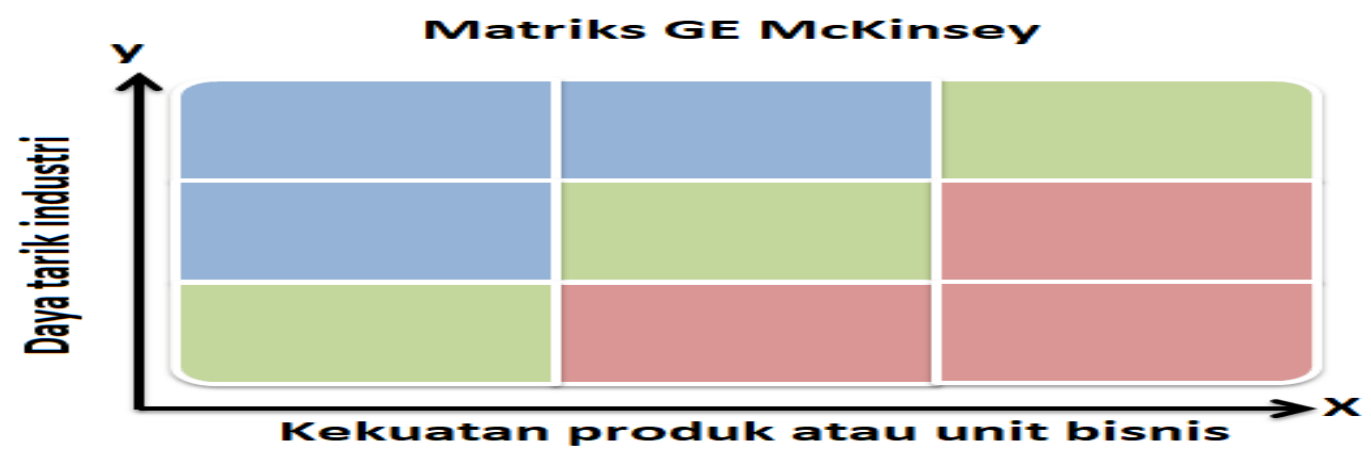

Pada tahun 1970-an, General Electric mengelola portofolio besar dan rumit dari produkproduk yang tidak terkait dan tidak puas dengan keuntungan dari investasinya dalam produk. Pada saat itu, perusahaan biasanya bergantung pada proyeksi arus kas masa depan, pertumbuhan pasar di masa depan atau beberapa proyeksi masa depan lainnya untuk membuat keputusan investasi, yang merupakan metode yang tidak dapat diandalkan untuk mengalokasikan sumber daya. Oleh karena itu, GE berkonsultasi dengan McKinsey \& Company dan sebagai hasilnya kerangka sembilan kotak dirancang. Matriks sembilan kotak memetakan BU pada 9 elemen yang menunjukkan apakah perusahaan harus berinvestasi dalam produk, memanen / melepaskannya atau melakukan penelitian lebih lanjut pada produk dan berinvestasi di dalamnya jika masih ada sumber daya yang tersisa. BU dievaluasi pada dua sumbu: daya tarik industri dan kekuatan kompetitif unit. 


\section{Daya Tarik Industri}

Daya tarik industri menunjukkan betapa sulit atau mudahnya suatu perusahaan bersaing di pasar dan memperoleh laba. Semakin menguntungkan industri adalah semakin kuat daya tariknya. Ketika mengevaluasi daya tarik industri, analis harus melihat bagaimana industri akan berubah dalam jangka panjang dibandingkan dalam waktu dekat, karena investasi yang diperlukan untuk produk biasanya memerlukan komitmen jangka panjang.

Daya tarik industri terdiri dari banyak faktor yang secara kolektif menentukan tingkat persaingan di dalamnya. Tidak ada daftar pasti tentang faktor mana yang harus dimasukkan untuk menentukan daya tarik industri, tetapi yang berikut adalah yang paling umum:

a. Tingkat pertumbuhan jangka panjang

b. Ukuran industri

c. Profitabilitas industri: hambatan masuk, hambatan keluar, kekuatan pemasok, kekuatan pembeli, ancaman pengganti, dan pelengkap yang tersedia (gunakan analisis Five Forces dari Porter untuk menentukan ini)

d. Struktur industri (gunakan kerangka Struktur-Perilaku-Kinerja untuk menentukan ini)

e. Perubahan siklus hidup produk

f. Perubahan permintaan

g. Tren harga

h. Faktor lingkungan makro (gunakan PEST atau PESTEL untuk ini)

i. Musiman

j. Ketersediaan tenaga kerja

k. Segmentasi pasar

\section{Kekuatan kompetitif dari unit bisnis atau produk}

Sepanjang sumbu $\mathrm{X}$, matriks mengukur seberapa kuat, dalam hal persaingan unit bisnis tertentu melawan saingannya. Dengan kata lain, para manajer mencoba untuk menentukan apakah suatu unit bisnis memiliki keunggulan kompetitif yang berkelanjutan (atau setidaknya keunggulan kompetitif sementara) atau tidak. Jika perusahaan memiliki keunggulan kompetitif yang berkelanjutan, pertanyaan berikutnya adalah: "Untuk berapa lama akan dipertahankan?"
a. Faktor-faktor berikut menentukan kekuatan kompetitif unit bisnis:
b. Total pangsa pasar
c. Pertumbuhan pangsa pasar dibandingkan dengan saingan 
d. Kekuatan merek (gunakan nilai merek untuk ini)

e. Profitabilitas perusahaan

f. Kesetiaan pelanggan

g. Sumber daya atau kemampuan VRIO (gunakan kerangka VRIO untuk menentukan ini)

\section{KESIMPULAN}

Berdasarkan dari uraian di atas maka sebagai penutup, bahwa manajemen suatu perusahaan dapat menggunakan strategi analisis bisnis dari berbagai model analisis dalam menganalisis strategi bisnisnya yang digunakan dalam rangka untuk memudahkan para lini bisnis dalam menerjemahkan perencanaan strategi perusahaan kedalam bahasa yang lebih mudah dan strategis dengan alat analisis yang ditetapkan sesuai dengan bidang bisnis yang dilakukannya.

Masing-masing alat analisis bisnis tersebut mempunyai berbagai kelemahan dan kelebihannya, tentu manajemen akan menyesuaikan alat analisis mana yang lebih tepat dan akurat dalam menguraikan strategi bisninya berdasarkan alat analisis yang diperlukannya. Sebagai panduan kerja analisis bagi perusahaan sehingga positioning perusahaan dapat diketahui bersama berdasarkan model analisis bisnis tersebut.

\section{DAFTAR PUSTAKA}

David W. Cravens. 2008. Pemasaran Strategis, cetakan 3. Jakarta: Erlangga.

Iwan Purwanto. 2006. Manajemen Strategi. CV. Yrama Widya, Bandung.

John A.Pearce II \& Richard B.Robinson, terj. Agus Maulana,Ir, M.S.M, 1998. Manajemen Strategik Jilid 1. Binarupa Aksara, Tangerang.

M.Taufiq Amir. 2011. Manajemen Strategik Konsep dan Aplikasi. Jakarta: Rajawali Pers.

M. Yusuf S. Barusman dan Soni Gunardi, Analisis Portofolio Produk pada PT. Asuransi Umum Bumi Putera Muda 1967 Cabang Lampung menggunakan Matrik Baston Consulting Group, Vol. 4 No. 2 April 2014 hal.141. ubl.ac.id diakses pada tanggal 02 July 2020.

Setiawan Hari Purwanto dan Zulkieflimansyah. 2009. Manajemen Strategi. Jakarta: FEUI.

Yanuar Surya Putra, Analisis Matriks Boston Consulting Grup (BCG) pada Sepeda Motor Merek Honda (Studi Kasus pada PT. Astra Honda Motor Tahun 2013,) Vol. 7 No. 13, Juli 2014. Jusuf Udayana, Lic,Ec, dkk, 2013. Manajemen Strategy. Yogyakarta: Graha Ilmu. 